\title{
Smoke of extreme Australian bushfires observed in the stratosphere over Punta Arenas, Chile, in January 2020: optical thickness, lidar ratios, and depolarization ratios at 355 and $532 \mathrm{~nm}$
}

\author{
Kevin Ohneiser ${ }^{1}$, Albert Ansmann ${ }^{1}$, Holger Baars ${ }^{1}$, Patric Seifert ${ }^{1}$, Boris Barja ${ }^{2}$, Cristofer Jimenez ${ }^{1}$, \\ Martin Radenz ${ }^{1}$, Audrey Teisseire ${ }^{1}$, Athina Floutsi ${ }^{1}$, Moritz Haarig ${ }^{1}$, Andreas Foth ${ }^{3}$, Alexandra Chudnovsky ${ }^{4}$, \\ Ronny Engelmann $^{1}$, Félix Zamorano ${ }^{2}$, Johannes Bühl ${ }^{1}$, and Ulla Wandinger ${ }^{1}$ \\ ${ }^{1}$ Leibniz Institute for Tropospheric Research, Leipzig, Germany \\ ${ }^{2}$ Atmospheric Research Laboratory, University of Magallanes, Punta Arenas, Chile \\ ${ }^{3}$ Leipzig Institute for Meteorology, University of Leipzig, Leipzig, Germany \\ ${ }^{4}$ Porter School of the Environment and Earth Sciences, Tel Aviv University, Tel Aviv, Israel
}

Correspondence: Kevin Ohneiser (ohneiser@tropos.de)

Received: 2 February 2020 - Discussion started: 4 February 2020

Revised: 17 June 2020 - Accepted: 18 June 2020 - Published: 10 July 2020

\begin{abstract}
We present particle optical properties of stratospheric smoke layers observed with multiwavelength polarization Raman lidar over Punta Arenas $\left(53.2^{\circ} \mathrm{S}, 70.9^{\circ} \mathrm{W}\right)$, Chile, at the southernmost tip of South America in January 2020. The smoke originated from the record-breaking bushfires in Australia. The stratospheric aerosol optical thickness reached values up to 0.85 at $532 \mathrm{~nm}$ in midJanuary 2020. The main goal of this rapid communication letter is to provide first stratospheric measurements of smoke extinction-to-backscatter ratios (lidar ratios) and particle linear depolarization ratios at 355 and $532 \mathrm{~nm}$ wavelengths. These aerosol parameters are important input parameters in the analysis of spaceborne CALIPSO and Aeolus lidar observations of the Australian smoke spreading over large parts of the Southern Hemisphere in January and February 2020 up to heights of around $30 \mathrm{~km}$. Lidar and depolarization ratios, simultaneously measured at 355 and $532 \mathrm{~nm}$, are of key importance regarding the homogenization of the overall Aeolus ( $355 \mathrm{~nm}$ wavelength) and CALIPSO (532 nm wavelength) lidar data sets documenting the spread of the smoke and the decay of the stratospheric perturbation, which will be observable over the entire year of 2020 . We found typical values and spectral dependencies of the lidar ratio and linear depolarization ratio for aged stratospheric smoke. At $355 \mathrm{~nm}$, the lidar ratio and depolarization ratio ranged from 53 to $97 \mathrm{sr}$ (mean $71 \mathrm{sr}$ ) and 0.2 to 0.26 (mean 0.23 ), respectively. At
\end{abstract}

$532 \mathrm{~nm}$, the lidar ratios were higher ( $75-112 \mathrm{sr}$, mean $97 \mathrm{sr}$ ) and the depolarization ratios were lower with values of 0.14 0.22 (mean 0.18). The determined depolarization ratios for aged Australian smoke are in very good agreement with respective ones for aged Canadian smoke, observed with lidar in stratospheric smoke layers over central Europe in the summer of 2017. The much higher $532 \mathrm{~nm}$ lidar ratios, however, indicate stronger absorption by the Australian smoke particles.

\section{Introduction}

Massive bushfires fueled by high, record-breaking temperatures were raging in southeastern Australia in the summer season of 2019-2020 after months of extreme drought (Australian Bureau of Meteorology, 2020). These were the worst wildfires in decades. The enormous fire activity triggered strong pyrocumulonimbus (pyro- $\mathrm{Cb}$ ) convection (Fromm and Servranckx, 2003; Fromm et al., 2010) in the last days of December 2019 and in January 2020 as our analysis revealed (Himawari, 2020; Himawari-KachelmannWetter, 2020; MODIS, 2020a). The pyro-Cb towers reached heights of up to $17 \mathrm{~km}$ (MODIS, 2020a) and lifted enormous amounts of fire smoke into the upper troposphere and lower stratosphere (UTLS) as will be discussed in Sect. 3. Absorp- 
tion of sunlight by the black-carbon-containing smoke particles caused warming of the smoke layers and further ascent of the aerosol particles (Boers et al., 2010; de Laat et al., 2012). The prevailing westerly winds transported the smoke layers to South America within 8-14d. The first stratospheric smoke layers of the 2019-2020 Australian burning season were detected with our lidar system over Punta Arenas, Chile, at the southernmost tip of South America on the evening of 5 January 2020 and since then almost continuously by the end of January 2020 (and still in July 2020). The layers over Punta Arenas reached heights of $25-30 \mathrm{~km}$ at the end of January caused by diabatic heating of the smoke layers.

Similar to the spread of the Canadian smoke which covered large parts of the lower stratosphere in the Northern Hemisphere in the summer and autumn of 2017 (Khaykin et al., 2018; Baars et al., 2019b; Hu et al., 2019; Kloss et al., 2019), we expect a strong perturbation in stratospheric aerosol conditions in the Southern Hemisphere in 2020. Similar to the Northern Hemispheric smoke event in 2017, the decay of the perturbation may last longer than 6 months (Baars et al., 2019b; Kloss et al., 2019). These significantly changed stratospheric aerosol conditions have the potential to sensitively influence radiative transfer (Boers et al., 2010; Ditas et al., 2018; Kloss et al., 2019; Yu et al., 2019), heterogeneous ice nucleation in cloud layers (Ullrich et al., 2017), and heterogeneous chemical reactions (Yu et al., 2019) by providing surfaces for, e.g., chlorine activation (McConnell and Jin, 2010). Furthermore, such events enrich the natural soot particle reservoir between 20 and $30 \mathrm{~km}$ (Renard et al., 2008).

The spaceborne CALIPSO (Cloud-Aerosol Lidar and Infrared Pathfinder Satellite Observation) lidar (Winker et al., 2009; Omar et al., 2009; Khaykin et al., 2018; Kar et al., 2019) and the Aeolus lidar of the European Space Agency (ESA) (Stoffelen et al., 2005; ESA, 2008; Lux et al., 2020; Witschas et al., 2020; Ansmann et al., 2007; Flamant et al., 2008) will significantly contribute to the monitoring and documentation of the spread of the smoke across the Southern Hemisphere and of the decay of the stratospheric perturbation in 2020. Passive remote sensing - as used by Khaykin et al. (2018), Ansmann et al. (2018), Hu et al. (2019), and Kloss et al. (2019) - to characterize the record-breaking 2017 smoke event in the Northern Hemisphere will be used as well.

In this rapid communication letter, we present the first measurements of the particle extinction-to-backscatter ratio (lidar ratio) and particle linear depolarization ratio at 355 and $532 \mathrm{~nm}$ for aged stratospheric smoke originating from the extreme Australian bushfires. The observations were performed with our multiwavelength polarization Raman lidar system (Polly; described in the next section) in Punta Arenas in southern Chile. These lidar and depolarization ratios are required as input parameters in the data analysis and homogenization of the spaceborne CALIPSO and Aeolus lidar measurements which are conducted at different laser wavelengths, namely at $355 \mathrm{~nm}$ in the case of the Aeolus lidar and $532 \mathrm{~nm}$ in the case of the CALIPSO lidar. On the one hand, $532 \mathrm{~nm}$ lidar ratios are needed, e.g., to accurately retrieve height profiles of the smoke light-extinction coefficients and of smoke aerosol optical thickness (AOT) by means of the CALIPSO lidar. On the other hand, $355 \mathrm{~nm}$ particle depolarization ratios are required in the retrieval of the total particle backscatter coefficient and the lidar ratio at $355 \mathrm{~nm}$ from Aeolus observations (Baars et al., 2019a). Lidar ratios and depolarization ratios measured simultaneously at both 355 and $532 \mathrm{~nm}$ wavelengths are a prerequisite in efforts to successfully homogenize the overall Aeolus-CALIPSO data set of smoke optical properties later on. Simultaneously measured lidar ratios and depolarization ratios are also important parameters in aerosol typing efforts (see, e.g., Burton et al., 2012, 2015; Groß et al., 2013; Nicolae et al., 2018; Papagiannopoulos et al., 2018) with lidars from ground and in space to improve optical models developed to simulate the smoke optical properties as a function of particle shape and size characteristics and composition (e.g., Kahnert, 2017; Liu and Mishchenko, 2018, 2020; Luo et al., 2019; Gialitaki et al., 2020). Thus, our Punta Arenas lidar observations in January 2020 can be regarded as an important contribution to the global library of aerosol optical properties.

\section{Lidar apparatus and data analysis}

The lidar observations in Punta Arenas $\left(53.2^{\circ} \mathrm{S}, 70.9^{\circ} \mathrm{W}\right.$; $9 \mathrm{~m}$ above sea level, a.s.1.), Chile, were conducted in the framework of the long-term DACAPO-PESO (Dynamics, Aerosol, Cloud And Precipitation Observations in the Pristine Environment of the Southern Ocean; https://dacapo. tropos.de, last access: 20 April 2020) campaign lasting from November 2018 to the end of 2020. The main goal of DACAPO-PESO is the investigation of aerosol-cloud interaction processes in rather pristine, unpolluted marine conditions. The mobile Leipzig Cloudnet supersite LACROS (Leipzig Aerosol and Cloud Remote Observation System; http://lacros.rsd.tropos.de/, last access: 20 April 2020) (Bühl et al., 2013, 2016; LACROS, 2020) was run continuously at the University of Magallanes (UMAG) in Punta Arenas and covered two summer and winter seasons of aerosol and cloud observations. LACROS is equipped with a multiwavelength polarization Raman lidar, a wind Doppler lidar, a $35 \mathrm{GHz}$ Doppler cloud radar, a ceilometer, a disdrometer, and a microwave radiometer. In addition, an AErosol RObotic NETwork (AERONET) sun photometer was operated (Holben et al., 1998; AERONET, 2020).

The Polly instrument (POrtabLle Lidar sYstem) (Engelmann et al., 2016) is the key instrument of LACROS for aerosol profiling, and it is installed inside a container. This lidar has 13 channels and continuously measures elastic and Raman backscatter signals at the laser wavelengths of 
355, 532, and $1064 \mathrm{~nm}$ and respective Raman backscattering wavelengths of 387 and $607 \mathrm{~nm}$ (nitrogen Raman scattering) and $407 \mathrm{~nm}$ (water vapor Raman scattering) (Baars et al., 2016, 2019b). These polarization Raman lidar observations permit us to determine height profiles of the particle backscatter coefficient at the laser wavelengths of 355 , 532, and $1064 \mathrm{~nm}$, particle extinction coefficients at 355 and $532 \mathrm{~nm}$, the particle linear depolarization ratio at 355 and $532 \mathrm{~nm}$, and the mixing ratio of water vapor to dry air by using the Raman lidar return signals of water vapor and nitrogen (Engelmann et al., 2016; Hofer et al., 2017; Dai et al., 2018). The linear depolarization ratio is defined as the crosspolarized-to-co-polarized backscatter ratio. "Co" and "cross" denote the planes of polarization parallel and orthogonal to the plane of linear polarization of the transmitted laser pulses, respectively.

Details of the stratospheric Polly data analysis including an uncertainty discussion is given in the recent publication of Baars et al. (2019b) on stratospheric smoke observations in the Northern Hemisphere. Auxiliary data are required in the lidar data analysis in form of temperature and pressure profiles in order to calculate and correct for Rayleigh backscatter and extinction influences on the measured lidar return signal profiles. For auxiliary meteorological observations, we used GDAS1 (Global Data Assimilation System 1) temperature and pressure profiles with $1^{\circ}$ horizontal resolution from the National Weather Service's National Centers for Environmental Prediction (GDAS, 2020). We checked the quality and accuracy of the GDAS1 profiles through a comparison with respective temperature and pressure profiles measured with radiosonde at Punta Arenas airport (daily launch at 12:00 UTC).

Furthermore, the HYSPLIT (HYbrid Single-Particle Lagrangian Integrated Trajectory) model (HYSPLIT, 2020; Stein et al., 2015; Rolph et al., 2017), based on GDAS1 reanalysis data, was used to calculate $13 \mathrm{~d}$ backward trajectories. Cloud observations with the Japanese geostationary weather satellite Himawari 8 (Himawari, 2020; Himawari-Kachelmann-Wetter, 2020) and with MODIS (Moderate Resolution Imaging Spectroradiometer) instruments (MODIS, 2020a) were analyzed to identify and characterize pyro-Cb events. CALIPSO lidar data (CALIPSO, 2020) were finally used to support the complex study of the long-range smoke transport across the Pacific Ocean.

\section{Observations}

\subsection{Smoke transport from Australia to southern South America}

The year 2019 was Australia's warmest and driest year on record (Australian Bureau of Meteorology, 2020). These extreme conditions favored strong and long-lasting bushfires during the summer months of 2019-2020. Vigorous, deep pyro- $\mathrm{Cb}$ convection developed over the fire areas in southeastern Australia and lifted large amounts of smoke into the UTLS height range. We counted pyro-Cb events over southeastern Australia and the adjacent regions over the Pacific Ocean on more than $20 \mathrm{~d}$ during the 1-month period from 20 December 2019 to 20 January 2020 by analyzing satellite observations (Himawari, 2020; Himawari-KachelmannWetter, 2020; MODIS, 2020a)

Based on a detailed forward and backward trajectory analysis (HYSPLIT, 2020), we distinguished three regimes of smoke transport. These regimes are highlighted in Fig. 1, and backward trajectories for case b in Fig. 1 are presented in Fig. 2. The first regime comprises smoke transport in the troposphere. Smoke injected over the source regions at heights below $10 \mathrm{~km}$ widely remained in the troposphere (Fig. 1a). Smoke injected into the UTLS regime at heights from about $12 \mathrm{~km}$ to about $16-17 \mathrm{~km}$ and remaining at heights below $19-20 \mathrm{~km}$ belong to the second transport regime. These smoke layers experienced fast eastward advection and reached Punta Arenas within about $10 \mathrm{~d}$. Such a case is shown in Fig. 1b and will be discussed in more detail below. The smoke layers ascended during the transport by efficient diabatic heating as a result of the strong absorption of solar radiation by the black-carbon-containing smoke particles and partly entered the stratospheric range above 19$20 \mathrm{~km}$ height. Figure 1c shows an example representing this third regime of smoke transport. The smoke-containing air mass (in Fig. 1c) crossed the Pacific Ocean eastward to about $100^{\circ} \mathrm{W}$ within $6 \mathrm{~d}$, according to HYSPLIT forward trajectories, starting at $37.1^{\circ} \mathrm{S}, 152^{\circ} \mathrm{E}$, i.e., over the western Pacific close to the coast of southeastern Australia at heights of 12 $17 \mathrm{~km}$ between 18 and 20 January 2020 (not shown). Caused by diabatic heating and lifting, the smoke layers reached heights above $19-20 \mathrm{~km}$ after about $6 \mathrm{~d}$ and moved forward with rather low speed. The backward trajectories for Punta Arenas with arrival heights from 20 to $28 \mathrm{~km}$ on $25-30 \mathrm{Jan}$ uary showed many circular movements west and southwest of Punta Arenas. As a consequence, the air masses stayed southwest of and over Punta Arenas for about $5 \mathrm{~d}$ according to OMI (ozone monitoring instrument) observations (OMI, 2020) and left the region not before 30 January 2020 . This extended smoke plume covered a region of about $2000 \mathrm{~km}$ (east to west) by $1000 \mathrm{~km}$ (north to south) and showed many $500 \mathrm{~nm}$ AOT pixels between 1 and 2 as a mean for the period from 20 to 31 January 2020 (OMI, 2020). The smoke layer in Fig. 1c with very sharp edges at $20.5 \mathrm{~km}$ (base) and $26 \mathrm{~km}$ height (top) belongs to this extended smoke field. We observed a stratospheric $532 \mathrm{~nm}$ AOT of about 0.35 on 29 January 2020 . This opportunity was used to learn more about the ascent rate of the smoke. An almost monotonic lifting was recorded. The top height of the smoke layer ascended with a constant rate of $1 \mathrm{~km} \mathrm{~d}^{-1}$ from 25 January (layer top at $22 \mathrm{~km}$ ) to 30 January (layer top at $27 \mathrm{~km}$ ). This unusual case will be further discussed in Sect. 3.2 based on Fig. 5 . 

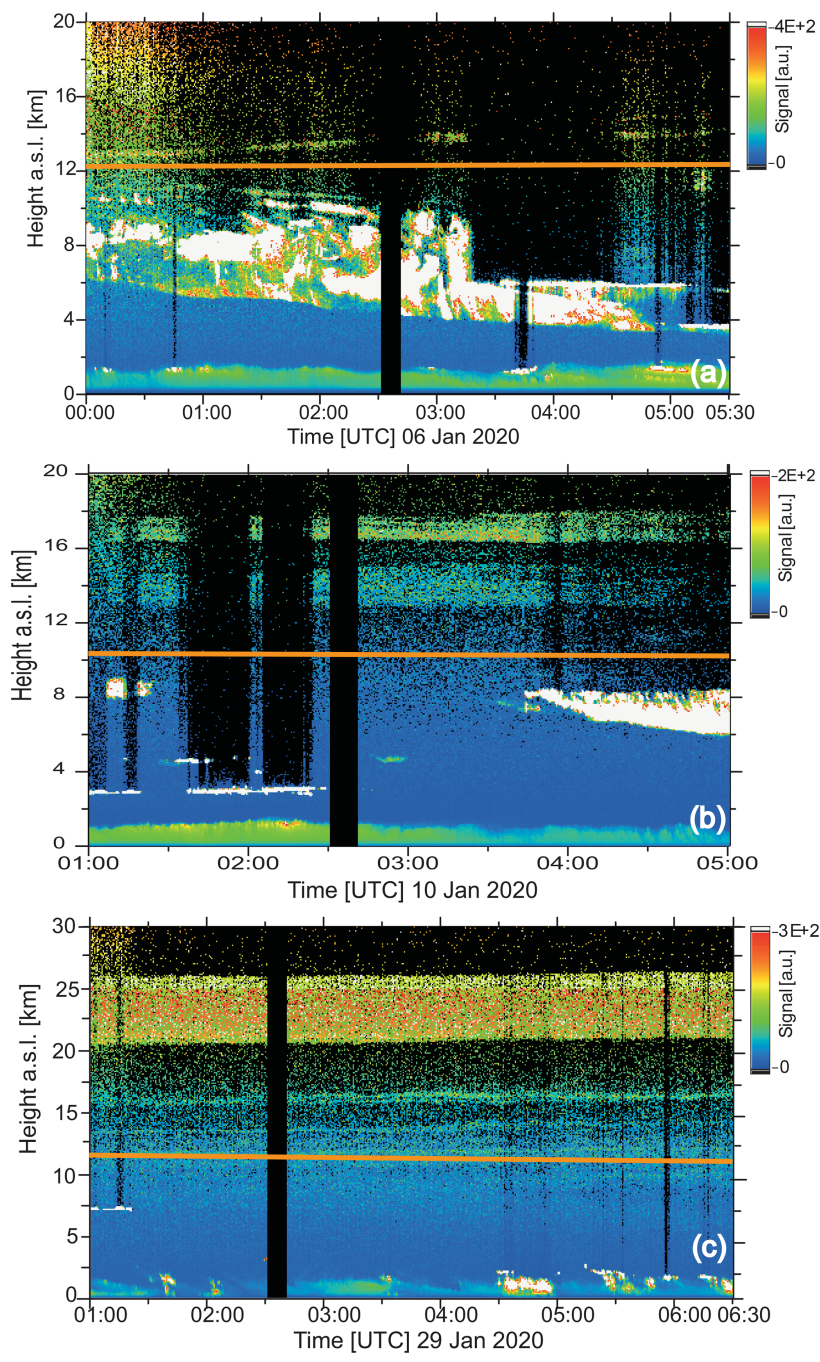

Figure 1. (a) Australian bushfire smoke in the troposphere, where the smoke layer extended from 6 to $11 \mathrm{~km}$ at 00:00 UTC and slowly descended with time, and in the stratosphere (a thin layer at $12.5 \mathrm{~km}$ in the beginning and at $14 \mathrm{~km}$ at the end on 6 January 2020). (b) Bushfire smoke in two layers from 13 to $15 \mathrm{~km}$ and from 16 to $18 \mathrm{~km}$ height on 10 January 2020. (c) Thin layers at 13 and $16 \mathrm{~km}$ and a dense bushfire smoke layer from 20 to $26 \mathrm{~km}$ height on 29 January 2020. The smoke was observed with the lidar in Punta Arenas, Chile, $10000 \mathrm{~km}$ downwind of the Australian fire areas. The range corrected $1064 \mathrm{~nm}$ signal is shown. The tropopause heights according to the Punta Arenas radiosonde (launched at 12:00 UTC, 08:00 local time) are given as orange horizontal lines. Black, column-like filaments above cloud layers (shown as white areas) indicate strong laser pulse attenuation. The large, well-defined black columns (from surface to $20 \mathrm{~km}$ ) indicate periods of automated depolarization calibration. The complex white areas in (a) above $4 \mathrm{~km}$ height indicate ice and mixed-phase clouds which caused ice virga formation (red and yellow). The clouds developed in smoke-containing air (green to blue with a few long-lasting coherent shallow smoke layers in yellow below and above the tropopause). These rather complex cloud features may be related to the occurrence of enhanced levels of smoke INPs (ice-nucleating particles) in the usually very pristine free troposphere with a low amount of very inefficient marine INPs (Kanitz et al., 2011).
Figure 2 provides an impression of the air mass transport from the forest fire regions in southeastern Australia to the southern part of South America. The respective smoke observation in Punta Arenas on 10 January 2020 is shown in Fig. 1b. We performed a detailed HYSPLIT trajectory analysis with 5-13d forward trajectories starting close to the coast of southeastern Australia at heights from 12 to $17 \mathrm{~km}$ between 29 December 2019 and 1 January 2020 and $10-13 \mathrm{~d}$ backward trajectories arriving at Punta Arenas above the tropopause between 8 and 11 January 2020 (HYSPLIT, 2020). Based on the trajectory analysis together with the study of pyro-Cb events over southeastern Australia (Himawari, 2020; Himawari-KachelmannWetter, 2020) and the corresponding Cb top heights, temperatures, and thus maximum possible smoke injection heights (MODIS, 2020a), the following synergistic picture on the smoke transport from southeastern Australia to the southern parts of South America between 28 December 2019 and 10 January 2020 was obtained. A period with coherent and intense pyro- $\mathrm{Cb}$ developments, triggered by the extreme fires, started on 28 December 2019 (00:00 UTC) and lasted for almost $4 \mathrm{~d}$. The strongest pyro-Cb clusters occurred from 30 December, 07:00 UTC, to 31 December 2019, 12:0015:00 UTC. Huge cloud complexes formed with horizontal extents of $150 \mathrm{~km} \times 250 \mathrm{~km}$ to $350 \mathrm{~km} \times 750 \mathrm{~km}$ (Himawari, 2020; Himawari-Kachelmann-Wetter, 2020), and the cloud tops partly reached $16-17 \mathrm{~km}$ height (MODIS, 2020a). These cloud towers lifted large amounts of smoke into the UTLS region, mostly up to $15-16 \mathrm{~km}$ height.

After the dissolution of the clouds, the released smoke absorbed solar radiation, heated the air, and probably ascended with a rate of about $1-2 \mathrm{~km} \mathrm{~d}^{-1}$ during the first $3 \mathrm{~d}$ after injection as long as the stratospheric smoke AOT (at $550 \mathrm{~nm}$ ) was on the order of 2 or more, as was the case according to satellite observations over the Pacific east of Australia (MODIS, 2020b; CALIPSO, 2020; Torres et al., 2020b). Torres et al. (2020b) reported $388 \mathrm{~nm}$ AOT values of 1 to $>5$ in a large smoke field east of New Zealand on 2 January 2020. This smoke field was linked to the pyro-Cb activity over southeastern Australia on 30-31 December 2019. This smoke crossed Punta Arenas on 9-10 January 2020. After about 3d, the ascent rate may have been much lower at much lower AOTs over the remote Pacific Ocean. We assume a further ascent of around $2 \mathrm{~km}$ during the residual $7 \mathrm{~d}$ of the travel towards Punta Arenas. This hypothesis of a strong ascent is in good agreement with modeling studies of ascent rates of Australian smoke layers originating from the rather strong Black Saturday fires (occurring on 7 February 2009 in the Melbourne area) by de Laat et al. (2012). A similar ascent of smoke layers by $5-8 \mathrm{~km}$ was observed with CALIPSO during the $10 \mathrm{~d}$ transport of smoke layers from the western Canadian fire sources to Leipzig, Germany, in mid-August 2017 (Torres et al., 2020a). Thus, all in all, the Australian smoke layers probably ascended by $5-7 \mathrm{~km}$ within $10 \mathrm{~d}$ on the way from southeastern Australia to Punta Arenas. This ascent has to 

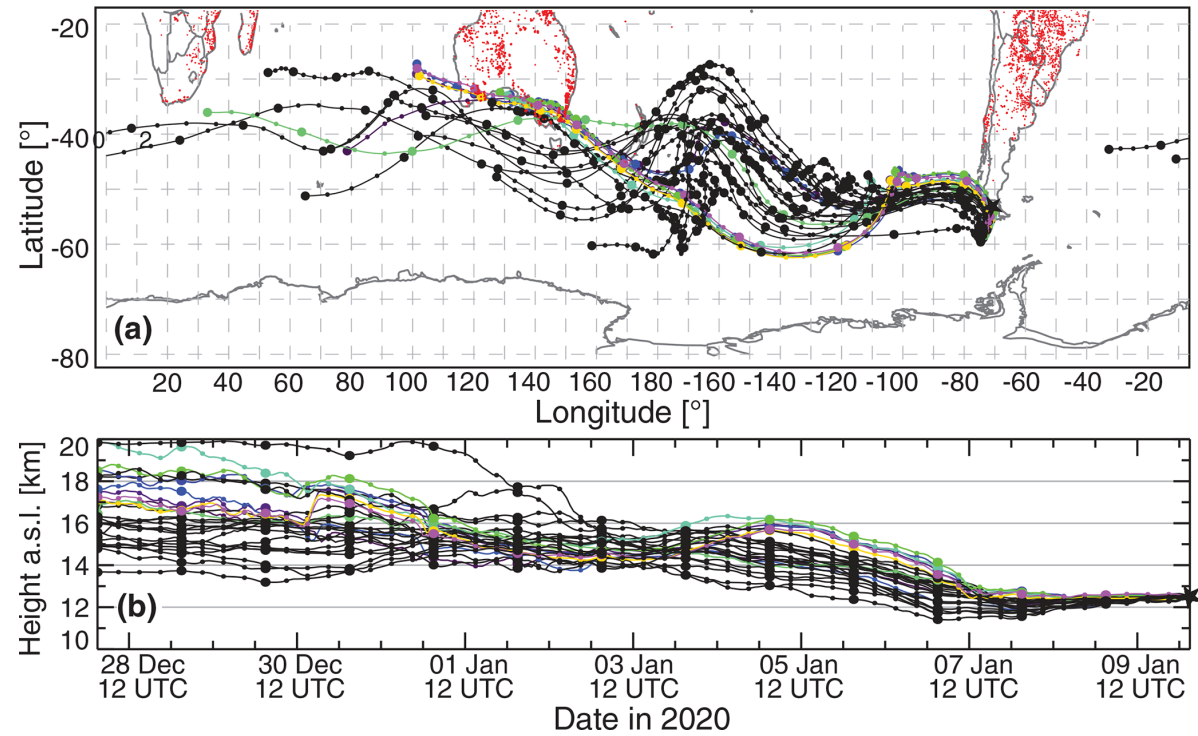

Figure 2. The 13-d backward trajectories (HYSPLIT, 2020) arriving at Punta Arenas (black star) on 10 January 2020, 03:00 UTC at 12.5 km height a.s.l. The colored backward trajectories crossed the bushfire and pyro- $\mathrm{Cb}$ areas in southeastern Australia and downwind over the adjacent Pacific Ocean on 30-31 December 2020. Fires occurring between 21 and 30 December 2019 are given as red dots (in a) and provided by FIRMS (2020).

be taken into consideration in the interpretation of our backward trajectory computations which ignore any diabatic heating effect on air motion.

According to the backward trajectories in Fig. 2, the smoke injection heights were at about 16-17 km height over the identified pyro- $\mathrm{Cb}$ areas. This finding is in agreement with the discussion by Torres et al. (2020b) about smoke injection heights required to explain the presented satellitebased AOT observations east of New Zealand on 2 January 2020. All backward trajectories that crossed the pyro$\mathrm{Cb}$ areas on 30-31 December 2019 at heights between 14 and $17 \mathrm{~km}$ (colored trajectories) arrived at Punta Arenas between about 11 and $13 \mathrm{~km}$ height (the $12.5 \mathrm{~km}$ trajectory ensemble is given in Fig. 2). These air masses descended by about 3$5 \mathrm{~km}$ on their transport over the $10000 \mathrm{~km}$ distance because of the large-scale meteorological conditions. This descent of the smoke layers was then obviously overcompensated by the assumed ascent by $5-7 \mathrm{~km}$ so that finally the smoke was observed between 13 and $15 \mathrm{~km}$ height and not between 11 and $13 \mathrm{~km}$ as the backward trajectories suggested.

We observed another layer on 10 January 2020 (Fig. 1b; $16-18 \mathrm{~km}$ height). The respective backward trajectory analysis (not shown) indicates that this smoke layer needed about $2 \mathrm{~d}$ more than the lower smoke layer to reach Punta Arenas. The air masses had thus $2 \mathrm{~d}$ more to absorb solar radiation and thus to ascend to greater heights.

The CALIPSO observations analyzed from 19 December 2019 to 14 January 2020 (CALIPSO, 2020) corroborate our explanation of the smoke transport. A coherent flow of smoke from southeastern Australia to southern South America was found mainly in the stratosphere, including an in- crease in the smoke layer top height with increasing transport time. More details of the CALIPSO observations and comparison with our ground-based lidar measurements will be presented in a follow-up article focusing on the entire recordbreaking stratospheric Australian smoke event in 2020.

It is worth noting that Foth et al. (2019) discuss a similar bushfire case observed with a Polly instrument at the same site of Punta Arenas in March 2010 (Kanitz et al., 2011). This case was associated with the occurrence of pyro-Cb over western Australia. Similar long-range transport characteristics were found for the smoke in the upper troposphere at about $12 \mathrm{~km}$ height over Punta Arenas in March 2010. The study was based on comprehensive atmospheric modeling in combination with CALIPSO lidar observations. The good agreement between the model results and the observations indicate that self-lifting effects were obviously rather weak in this case and could be ignored. Floutsi et al. (2020) summarized recent aerosol observations in the free troposphere over Punta Arenas (November 2018 to December 2019) and also found a smoke plume (at $11 \mathrm{~km}$ height) advected from southern Australia to Punta Arenas within 9-10 d in March 2019.

\subsection{Lidar observations of smoke optical properties}

Figure 3 presents an example of a lidar measurement of stratospheric smoke over Punta Arenas in January 2020. The full set of derivable smoke optical properties is shown. The 2$\mathrm{h}$ mean profiles of the particle backscatter and extinction coefficients and respective extinction-to-backscatter ratios (lidar ratios), as well as of the particle linear depolarization ratios at 355 and $532 \mathrm{~nm}$, are given, having been measured 


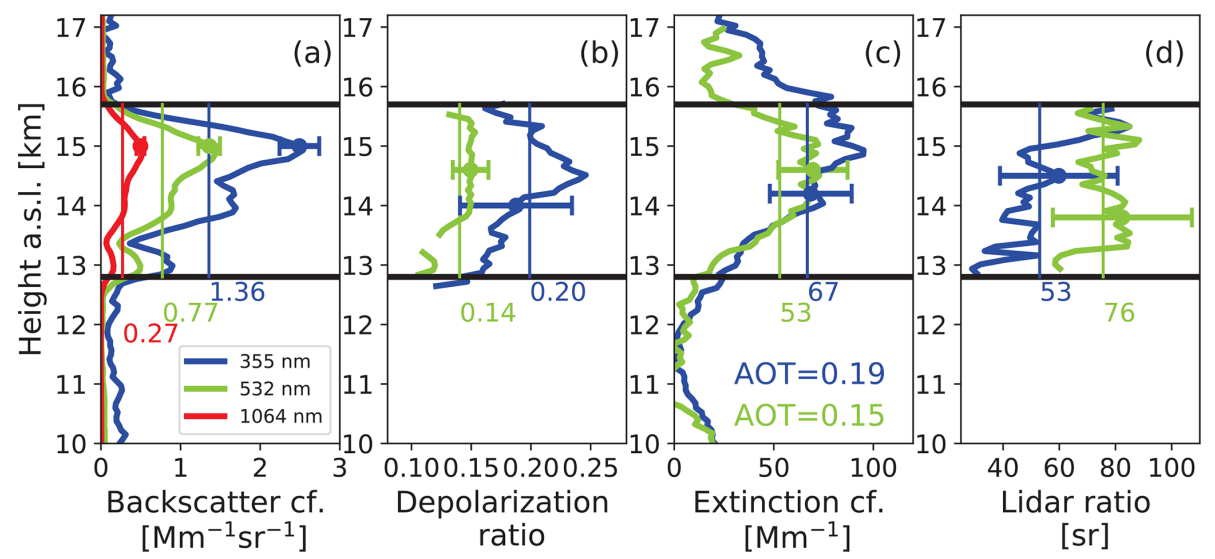

Figure 3. Profiles of smoke optical properties measured with the Polly lidar in the stratosphere over Punta Arenas on 9 January 2020 , 03:56-05:40 UTC. Base and top heights of the smoke layer are indicated by black horizontal lines. (a) Particle backscatter coefficient at three wavelengths, (b) particle linear depolarization ratio, (c) smoke extinction coefficient and AOT, and (d) smoke extinction-to-backscatter ratio (lidar ratio). Colored vertical lines from layer base to top indicate layer mean values (given also as numbers). Error bars show the estimated uncertainties. In (c) and (d), Raman signal smoothing with window lengths of 2000-2500 $\mathrm{m}$ was necessary so that the values around $14-15 \mathrm{~km}$ height represent best the extinction coefficients and lidar ratios of the $3 \mathrm{~km}$ deep smoke layer.

with the polarization Raman lidar Polly in the early morning of 9 January 2020. Signal smoothing was applied with window lengths of 500-700 $\mathrm{m}$ in the case of the backscatter coefficient and depolarization ratio profiles and 2000$2500 \mathrm{~m}$ in the case of the extinction coefficient and lidar ratio profiles. The backscatter coefficients were inter-calibrated in a thin cirrus layer between 6 and $8 \mathrm{~km}$ height assuming wavelength-independent cirrus backscattering and are thus very accurate. The results are noisy (especially for $355 \mathrm{~nm}$, affected by strong Rayleigh attenuation) because the Polly lidar is designed and optimized for tropospheric aerosol observations and not just for the monitoring of stratospheric aerosol events as mentioned already by Baars et al. (2019b). Nevertheless, the layer mean values for the different optical parameters, highlighted as vertical lines in Fig. 3, provide a clear picture of the optical properties and the underlying shape, size, and composition characteristics of the aged stratospheric smoke particles. As is typical for aged smoke, the spectral dependency of the backscatter coefficient is strong, whereas the wavelength dependence of the extinction coefficient (for the short wavelength range from 355 to $532 \mathrm{~nm}$ ) is weak. As a consequence, the lidar ratio is significantly larger at $532 \mathrm{~nm}$ compared to $355 \mathrm{~nm}$. The measured depolarization ratios of around $0.2(355 \mathrm{~nm})$ and 0.15 $(532 \mathrm{~nm})$ are also typical for aged smoke for upper tropospheric and stratospheric heights, as was found by Burton et al. (2015), Haarig et al. (2018), and Hu et al. (2019). If the smoke particles would have had an ideal spherical shape (consisting of a black carbon core and a thick organic carbon shell), the depolarization ratio would have been close to zero (Haarig et al., 2018), as was observed for the Canadian smoke at heights in the middle troposphere. Slight deviations from the ideal spherical form in combination with the monomodal, narrow smoke size distribution (accumulation mode shifted to larger particles with a mode diameter of 600 to $700 \mathrm{~nm}$, absence of a coarse mode) (Dahlkötter et al., 2014; Haarig et al., 2018) lead to the observed enhanced depolarization values and the distinct wavelength dependence, as recently modeled by Gialitaki et al. (2020) and also suggested by other modeling groups (e.g., Yu et al., 2019; Liu and Mishchenko, 2020). According to Yu et al. (2019), smoke particles consist of an insoluble black carbon (BC) core that is surrounded by an almost spherical shell of organic material and other atmospheric substances.

Table 1 summarizes seven analyzed smoke cases observed over Punta Arenas in January 2020. Layer mean values of geometrical and optical property layers for two pronounced smoke periods lasting from 8 to 11 January and from 25 to 30 January are given. During the second period (26-30 January), the analyzed smoke layers were at heights above 1920 km (Sect. 3.1; smoke transport regime 3). The $387 \mathrm{~nm}$ Raman signal profiles were very noisy at heights above $20 \mathrm{~km}$ so that a retrieval of $355 \mathrm{~nm}$ smoke extinction profiles were no longer possible. Even the cross-polarized $355 \mathrm{~nm}$ signals were too noisy for a trustworthy determination of the respective depolarization ratio (28-30 January 2020). To provide at least estimated pairs of 355 and $532 \mathrm{~nm}$ lidar ratios even for these cases, we used accompanying Punta Arenas AERONET photometer observations of 380 and $500 \mathrm{~nm}$ AOTs (AERONET, 2020) to calculate the respective extinction wavelength dependence for the short wavelength range and applied this wavelength dependence to the $532 \mathrm{~nm}$ extinction profiles to estimate the respective profiles of the $355 \mathrm{~nm}$ smoke extinction coefficient. Afterwards we estimated the $355 \mathrm{~nm}$ smoke AOT and layer mean smoke lidar ratios by combining the measured $355 \mathrm{~nm}$ layer mean 
Table 1. Smoke layer mean values of lidar ratios (LR) and depolarization ratios (DR) simultaneously measured at 355 and $532 \mathrm{~nm}$ on 3 subsequent days in January 2020. Tropopause height (TPH), layer base height (LBH), geometrical depth (LGD), and AOT of the stratospheric smoke layers are given in addition. Wavelength (in $\mathrm{nm}$ ) is indicated in parentheses. The uncertainty in the layer mean values is mainly caused by signal noise estimated to be about $10 \%$ (DR, $532 \mathrm{~nm}$ ), $20 \%$ (LR, $532 \mathrm{~nm}, \mathrm{DR}, 355 \mathrm{~nm}$ ), and $30 \%$ (LR, $355 \mathrm{~nm}$ ). For comparison, values for aged Canadian smoke measured over Leipzig, Germany, in August 2017 are given in the last line (Haarig et al., 2018). AERONET photometer observation of AOT wavelength dependence for the short wavelength spectral range (380-500 nm) is used to estimate $355 \mathrm{~nm}$ smoke AOT, extinction coefficient, and lidar ratio from the lidar measurements at $532 \mathrm{~nm}$. These value are also given in parentheses (2630 January 2020).

\begin{tabular}{|c|c|c|c|c|c|c|c|c|c|}
\hline Date & $\begin{array}{l}\mathrm{TPH} \\
(\mathrm{km})\end{array}$ & $\begin{array}{l}\mathrm{LBH} \\
(\mathrm{km})\end{array}$ & $\begin{array}{l}\text { LGD } \\
(\mathrm{km})\end{array}$ & AOT(355) & $\operatorname{AOT}(532)$ & $\begin{array}{r}\mathrm{LR}(355) \\
(\mathrm{sr})\end{array}$ & $\begin{array}{r}\mathrm{LR}(532) \\
(\mathrm{sr})\end{array}$ & $\mathrm{DR}(355)$ & $\operatorname{DR}(532)$ \\
\hline 8 Jan 2020, 04:30-06:30 UTC & 8.8 & 13.0 & 1.6 & 0.07 & 0.05 & 83 & 102 & 0.23 & 0.14 \\
\hline 9 Jan 2020, 03:56-05:40 UTC & 8.9 & 12.8 & 2.9 & 0.19 & 0.15 & 53 & 76 & 0.20 & 0.14 \\
\hline 10 Jan 2020, 02:25-04:20 UTC & 10.2 & 16.3 & 2.7 & 0.21 & 0.14 & 97 & 104 & 0.26 & 0.15 \\
\hline 26 Jan 2020, 04:27-06:19 UTC & 9.8 & 19.3 & 3.6 & $(0.28)$ & 0.16 & $(75)$ & 112 & 0.22 & 0.20 \\
\hline 28 Jan 2020, 05:15-07:29 UTC & 8.7 & 20.6 & 4.4 & $(0.49)$ & 0.33 & $(56)$ & 75 & - & 0.19 \\
\hline 29 Jan 2020, 01:45-04:14 UTC & 10.8 & 20.5 & 5.7 & $(0.53)$ & 0.31 & (70) & 106 & - & 0.21 \\
\hline 30 Jan 2020, 02:05-04:30 UTC & 11.8 & 22.0 & 5.1 & $(0.45)$ & 0.26 & (66) & 103 & - & 0.22 \\
\hline 22 Aug 2017, 20:45-00:30 UTC & 11.0 & 15.0 & 1.0 & 0.20 & 0.23 & 40 & 66 & 0.22 & 0.18 \\
\hline
\end{tabular}

backscatter coefficients with the estimated $355 \mathrm{~nm}$ extinction coefficients. The resulting lidar ratios are given in parentheses in Table 1. This approach is fully reliable when keeping in consideration that the $500 \mathrm{~nm}$ AOT (column integrated tropospheric and stratospheric extinction coefficient) is typically around 0.03 in this pristine region of the world, and the AOT values, measured in the second half of January 2020, were mainly between 0.2 and 0.35 and thus clearly dominated by the contribution of light extinction by the smoke particles. We applied this combined lidar-photometer method even to the 8-10 January period and found good agreement (not shown here) between the directly determined and estimated $355 \mathrm{~nm}$ lidar ratios.

Large lidar ratios of $75-112 \mathrm{sr}$ were observed at $532 \mathrm{~nm}$ indicating strongly absorbing BC containing smoke particles. The lidar ratios at $355 \mathrm{~nm}$ were systematically lower, partly by more than $30 \mathrm{sr}$ compared to the ones for $532 \mathrm{~nm}$. This is an unambiguous indication for aged smoke. A review on smoke lidar ratios and depolarization ratios in the troposphere and stratosphere can be found in Haarig et al. (2018). The mean lidar ratios of the seven cases in Table 1 are $71 \mathrm{sr}$ for $355 \mathrm{~nm}$ and $97 \mathrm{sr}$ for $532 \mathrm{~nm}$. For the depolarization ratios, we obtain mean values of $0.23(355 \mathrm{~nm})$ and $0.18(532 \mathrm{~nm})$. Without going into details here, which may be found in Ansmann et al. (2007), Wandinger et al. (2015), and Baars et al. (2019a), the Aeolus lidar transmitting circularly polarized laser pulses at $355 \mathrm{~nm}$ would have measured an apparent $355 \mathrm{~nm}$ lidar ratio of a factor of 1.6 higher than that observed with Polly, in this case with a particle depolarization ratio of 0.23 at $355 \mathrm{~nm}$. In the case of the apparent lidar ratio, light-depolarization is ignored in the Aeolus data analysis.

Next, we compared the mean lidar ratios and depolarization ratios of the Australian bushfire smoke event with the
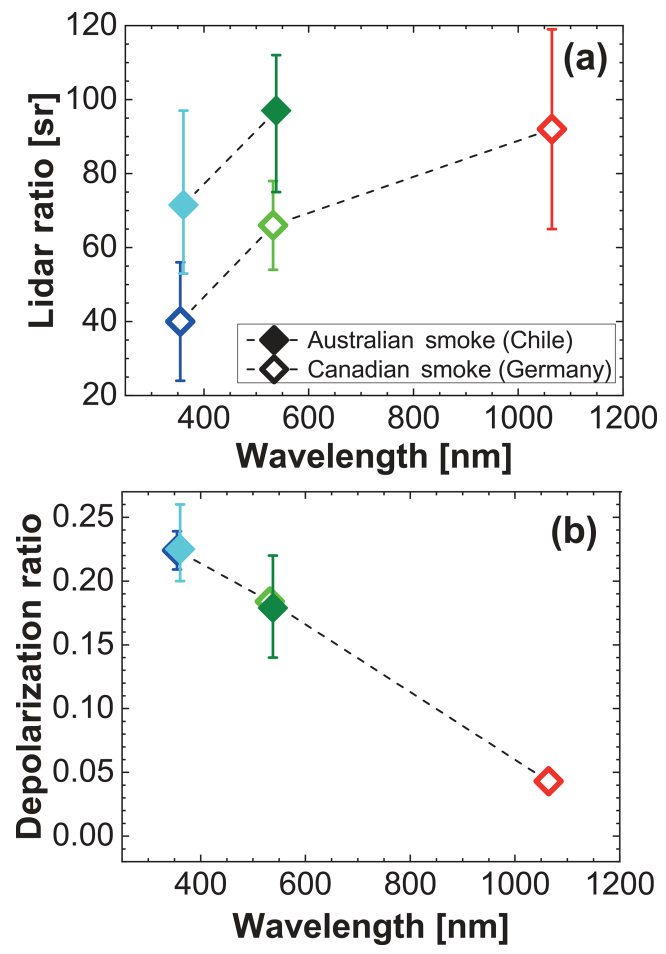

Figure 4. Comparison of the spectral dependence of (a) the lidar ratio and (b) the particle linear depolarization ratio of aged Canadian and Australian smoke as measured in the stratosphere over Leipzig, Germany, on 22 August 2017 (open symbols) and over Punta Arenas, Chile, in January 2020 (closed symbols). In the case of the Australian smoke, mean values of the seven cases in Table 1 are shown, and the vertical bar indicates the full range of found values. In the case of the Canadian smoke values (measurement case from 22 August 2017), vertical bars show the retrieval uncertainty. 
ones observed during the record-breaking Canadian smoke season in Leipzig, Germany, during the night of 22-23 August 2017 (see Table 1, last line). This comparison is highlighted in Fig. 4. The similarity of the spectral slopes of the lidar and depolarization ratios for stratospheric Canadian and Australian smoke after long-range transport over more than $10000 \mathrm{~km}$ in the Northern Hemisphere (2017) and in the Southern Hemisphere (2020) is surprising. Very similar depolarization ratio values point to the same shape and size characteristics of aged Canadian and Australian smoke in the stratosphere. Even the depolarization ratio at $1064 \mathrm{~nm}$ could be measured at the central European lidar station of Leipzig, Germany, in the case of Canadian smoke (Haarig et al., 2018). The strong wavelength dependence of the depolarization ratio from 355 to $1064 \mathrm{~nm}$ and the very low $1064 \mathrm{~nm}$ depolarization ratio values are a strong hint that coarse mode smoke particles were absent in the stratosphere.

In contrast to the Canadian and Australian smoke depolarization ratios, the lidar ratios are very different. This difference points to a much stronger light absorption by the Australian smoke particles and is probably related to the different burning material. Australian's forests mainly consist of eucalyptus trees, whereas western Canadian tree types are predominantly pine, fir, aspen, and cedar. For completeness, high $532 \mathrm{~nm}$ lidar ratios were also observed in the case of wildfire smoke originating from central Africa (Tesche et al., 2011) and from South Africa (Giannakaki et al., 2016). The African lidar ratios for 355 and $532 \mathrm{~nm}$ were found to be almost equal (no pronounced wavelength dependence) which, in turn, is an indication that the measured smoke was relatively fresh (of regional origin), and not aged as observed over Punta Arenas.

Figure 5 (together with Table 1) provides a summarizing overview of our stratospheric lidar observations in Punta Arenas in January 2020. The evolution of the stratospheric perturbation over the southernmost tip of South America is shown in terms of $532 \mathrm{~nm}$ smoke AOT, the respective stratospheric mean $532 \mathrm{~nm}$ extinction coefficient, and the smoke lidar ratios for both wavelengths. The $355 \mathrm{~nm}$ lidar ratios in Fig. 5 are exclusively derived by means of the lidarphotometer retrieval method.

As can be seen in Fig. 5a, a two-layer structure developed with a lower layer at heights below about $18 \mathrm{~km}$ (Sect. 3.1, smoke transport regime 2) and above $18 \mathrm{~km}$ height (smoke transport regime 3). Vertical depths ranged from a few hundred meters up to several kilometers and partly reached values of $6 \mathrm{~km}$. The depolarization ratio observations suggest even different smoke types (or different ages) with slightly different shape properties in the lower and upper layers. The higher depolarization ratios indicating less spherical particle shapes are found in the upper layer.

The ascent of the smoke layer above $20 \mathrm{~km}$ is visible between 25 and 30 January. As discussed in Sect. 3.1, this layer observed over Punta Areas was part of a large smoke field (with an extent of $1000 \mathrm{~km} \times 2000 \mathrm{~km}$ ). According to OMI

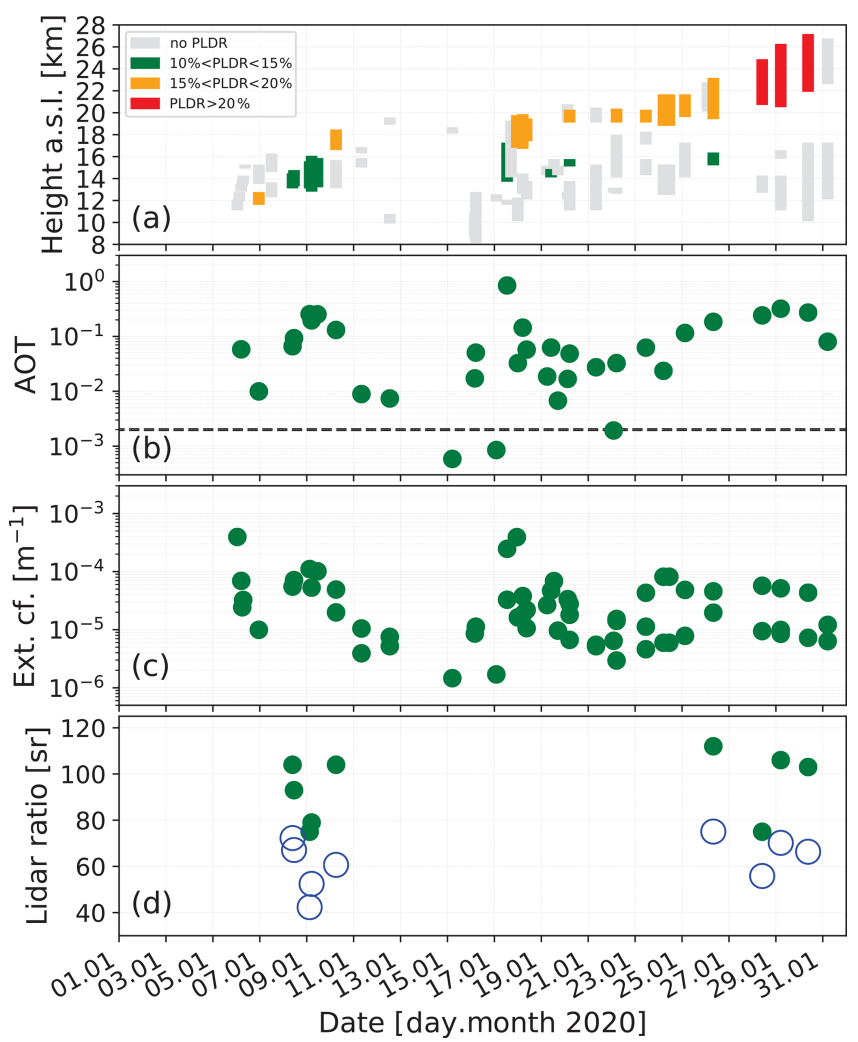

Figure 5. (a) Overview of Polly observations of stratospheric smoke layers (thick bars) from 6 to 31 January 2020. The color of the bar indicates the layer mean $532 \mathrm{~nm}$ particle linear depolarization ratio (PLDR). If no trustworthy PLDR solution could be obtained, the bars are gray. (b) $532 \mathrm{~nm}$ AOT of the stratospheric smoke, calculated from the profiles of the smoke backscatter coefficients multiplied by a lidar ratio of $95 \mathrm{sr}$, (c) layer mean $532 \mathrm{~nm}$ particle extinction coefficient, and (d) layer mean $532 \mathrm{~nm}$ lidar ratio (green) obtained from the nighttime Raman lidar measurements. The open blue circles indicate estimated $355 \mathrm{~nm}$ lidar ratios obtained by means of the combined lidar-photometer retrieval method (see text). The dashed horizontal line in (b) shows background AOT level for the Southern Hemispheric stratosphere (Sakai et al., 2016). The different smoke transport regimes below and above $19-20 \mathrm{~km}$ height as defined in Sect. 3.1 are responsible for the two layer structure (in a) observed after 20 January 2020.

(2020), the mean $500 \mathrm{~nm}$ AOT was around $0.6-0.7$ in this smoke field for the 20-31 January period, and mean peak values were close to 2. Punta Arenas was always at the rim of the smoke area. The lidar measured the highest stratospheric $532 \mathrm{~nm}$ AOTs of $0.25-0.35$ on 28-30 January 2020. As can be seen in Fig. 5a, the top height of the smoke layer steadily moved upward by $1 \mathrm{~km} \mathrm{~d}^{-1}$ from 25 to 30 January 2020 . Such a strong ascent rate of $1 \mathrm{~km} \mathrm{~d}^{-1}$ was also found by de Laat et al. (2012) for the Black Saturday fire smoke in February 2009, however for AOTs close to 3.5. Ascent rates of about $1 \mathrm{~km} \mathrm{~d}^{-1}$ were also derived from CALIPSO observations for the optically dense Canadian smoke layers in the 
summer 2017 during the first $5 \mathrm{~d}$ of long-range transport after the injection into the UTLS region on 13 August 2017 (Torres et al., 2020a). It should be mentioned that the backward trajectories arriving at Punta Arenas did not indicate any dynamically induced lifting during the 20-31 January 2020 period so that the observed ascent is probably entirely the result of the absorption of solar radiation by the black-carboncontaining smoke particles.

Figure $5 \mathrm{~b}$ shows that the $532 \mathrm{~nm}$ AOT was above the stratospheric background level of 0.002 by $1-2$ orders of magnitude in January 2020. Sakai et al. (2016) present stratospheric aerosol backscatter observations for Lauder, New Zealand, from 1992 to 2015. By assuming a typical lidar ratio of $50 \mathrm{sr}$ at $532 \mathrm{~nm}$ for stratospheric sulfuric acid droplets, the minimum column-integrated backscatter coefficients of Lauder correspond to minimum stratospheric AOT values of 0.002 (see dashed line in Fig. 5b).

The highest smoke-related $532 \mathrm{~nm}$ AOT value of 0.85 was found in the morning of 17 January 2020. The profile of the smoke backscatter coefficient was multiplied by the $532 \mathrm{~nm}$ smoke lidar ratio of $95 \mathrm{sr}$ to obtain an estimate for the $532 \mathrm{~nm}$ AOT. For a lidar ratio of $80 \mathrm{sr}$ (also a realistic smoke lidar ratio), the stratospheric AOT would decrease to 0.71 , a value close to the maximum $532 \mathrm{~nm}$ AOT of 0.6 observed over Leipzig during the midday hours on 22 August 2017 when the densest Canadian smoke plumes crossed Leipzig. The $532 \mathrm{~nm}$ AOT remained high with most values from 0.02 to 0.2 in January 2020. Most smoke extinction coefficients were on the order of $10-100 \mathrm{Mm}^{-1}$ in January 2020.

Finally, Fig. 5d shows the derived lidar ratios which were high with values mostly between 75 and $112 \mathrm{sr}$ at $532 \mathrm{~nm}$ and much lower values for the wavelength of $355 \mathrm{~nm}$. As mentioned, this unique wavelength dependence is a clear signature for aged smoke after long range transport. The opposite is the case, e.g, for urban haze and anthropogenic particles in general. Then the $355 \mathrm{~nm}$ lidar ratio is significantly higher than the $532 \mathrm{~nm}$ lidar ratio (Müller et al., 2005, 2007).

The ongoing lidar observations in Punta Arenas presently (until July 2020) show a very pronounced and geometrically deep smoke layer from about 10 to $20 \mathrm{~km}$ height, and frequently thin layers around $25 \mathrm{~km}$ height. The AOT values are still clearly above the background value. The stratospheric perturbation in the Southern Hemisphere, triggered by several periods with strong pyro-Cb activity over the southeastern Australian region in December and January 2020, was much stronger than the one in the Northern Hemisphere in the summer and autumn of 2017, which was related to only one strong pyro-Cb event which occurred on 12-13 August 2017 over western Canada (Peterson et al., 2018; Hu et al., 2019; Torres et al., 2020a).

\section{Conclusion and Outlook}

Important input parameters required for a trustworthy CALIPSO and Aeolus lidar data analysis of the stratospheric Australian smoke observations have been presented. Strong perturbations in stratospheric aerosol conditions with AOT up to 0.85 at $532 \mathrm{~nm}$ were recorded with lidar in Punta Arenas, Chile, in January 2020. The stratospheric smoke depolarization ratios of the Australian fire particles were found to be very similar to the ones observed over Europe in aged Canadian smoke in the summer of 2017. Mean values were 0.23 at $355 \mathrm{~nm}$ and 0.18 at $532 \mathrm{~nm}$. However, Australian smoke showed much higher lidar ratios (75-112 sr at $532 \mathrm{~nm}$ ) compared to the Canadian smoke lidar ratios, which indicates stronger light absorption. As is typical for aged smoke, the smoke lidar ratios at $355 \mathrm{~nm}$ were lower by 20 $30 \mathrm{sr}$, partly $>30 \mathrm{sr}$ compared to the values at $532 \mathrm{~nm}$.

The Polly observations will be ongoing until the end of the DACAPO-PESO campaign in late 2020 and thus will cover the entire bushfire season and most of the decay phase of the stratospheric perturbation in the Southern Hemisphere. As an outlook, follow-up publications are planned concerning the entire documentation of the unique smoke conditions in the troposphere and stratosphere over southern Chile in 2019 and 2020. This will include the analysis of CALIPSO and Aeolus lidar observations to describe the spread of the smoke in the Southern Hemisphere. We are also working on a detailed comparison of the record-breaking Northern Hemispheric smoke event (2017) with this record-breaking stratospheric perturbation in the Southern Hemisphere.

It is expected that the significantly increased particle concentration in the free troposphere over southern South America sensitively influenced cloud evolution and precipitation formation in this region with usually very low particle concentration of marine origin. Regarding future aerosol-cloud interaction studies in the framework of the DACAPO-PESO campaign, we plan to distinguish and separate time periods with and without smoke pollution from Australia to evaluate the potential impact of smoke on the occurrence and development of liquid-water, mixed-phase, and ice clouds and to continue in this way with our aerosol and cloud studies we started 10 years ago (Kanitz et al., 2011; Foth et al., 2019).

Data availability. Polly lidar observations (level 0 data, measured signals) are in the PollyNet database http://polly.rsd.tropos.de/ (PollyNET, 2020). LACROS observations (level 0 data) are stored in the Cloudnet database (http://lacros.rsd.tropos.de, LACROS, 2020). All the analysis products are available at TROPOS upon request (info@tropos.de). Backward trajectory analysis has been supported by air mass transport computation with the NOAA (National Oceanic and Atmospheric Administration) HYSPLIT (HYbrid Single-Particle Lagrangian Integrated Trajectory) model http://ready.arl.noaa.gov/HYSPLIT_traj.php (HYSPLIT, 2020). CALIPSO observations of smoke profiles and smoke AOTs are used (CALIPSO, 2020; FIRMS, 2020), as well as pyro-Cb cloud cluster 
satellite observations https://himawari8.nict.go.jp/ (Himawari, 2020), https://kachelmannwetter.com/de/sat/newsouthwales/ top-alarm-10min/20200123-1150z.html (Himawari-KachelmannWetter, 2020), and https://go.nasa.gov/2YdOaYH (MODIS, 2020a). The fire information used is provided by FIRMS (Fire Information for Resource Management System) (FIRMS, 2020).

Author contributions. The paper was written by $\mathrm{KO}$ and AA. The data analysis was performed by $\mathrm{KO}$ supported by $\mathrm{HB}, \mathrm{AA}, \mathrm{AF}, \mathrm{MH}$, and UW. All other co-authors are involved in the DACAPO-PESO campaign and took care of all measurements during several 4-week expeditions.

Competing interests. The authors declare that they have no conflict of interest.

Acknowledgements. We thank AERONET for their continuous efforts in providing high-quality measurements and products. Aerosol source apportionment analysis has been supported by air mass transport computation with the NOAA (National Oceanic and Atmospheric Administration) HYSPLIT (HYbrid Single-Particle Lagrangian Integrated Trajectory) model. We also thank the Himawari 8, Kachelmann-Wetter, CALIPSO, MODIS, VIIRS, and OMI teams for their well-organized easy-to-use internet platforms. Analyses and visualization tools were made available via the Giovanni online data system, developed and maintained by NASA's GES DISC. The MODIS and VIIRS information from the fires was provided by LANCE FIRMS operated by NASA, GSFC, and EOSDIS.

Financial support. TROPOS is involved in the Calibration/Validation (Cal/Val) activities of the Aeolus space mission in the frame of the German initiative EVAA (Experimental Validation and Assimilation of Aeolus observations) funded by the German Federal Ministry for Economic Affairs and Energy (BMWi) under grant no. (FKZ) 50EE1721C. The authors are also thankful for support through the European Research Infrastructure for the observations of Aerosol, Clouds, and Trace Gases Research Infrastructure (ACTRIS) under grant agreement no. 654109 and 739530 from the European Union's Horizon 2020 research and innovation program. We thank AERONET-Europe for providing an excellent calibration service. AERONET-Europe is part of the ACTRIS project. The DACAPO-PESO observations are partly funded by the German Science Foundation (DFG) project PICNICC under project number 408008112 .

The publication of this article was funded by the Open-Access Fund of the Leibniz Association.

Review statement. This paper was edited by Manvendra K. Dubey and reviewed by Michael Fromm and one anonymous referee.

\section{References}

AERONET: Aerosol Robotic Network aerosol data base, available at: http://aeronet.gsfc.nasa.gov/, last access: 20 April 2020.

Australian Bureau of Meteorology: Australian weather and climate information, available at: http://www.bom.gov.au/climate/ current/annual/aus/, last access: 20 April 2020.

Ansmann, A., Wandinger, U., Le Rille, O., Lajas, D., and Straume, A.: Particle backscatter and extinction profiling with the spacebornehigh-spectral-resolution Doppler lidar ALADIN: methodology and simulations, Appl. Optics, 46, 6606-6622, https://doi.org/10.1364/AO.46.006606, 2007.

Ansmann, A., Baars, H., Chudnovsky, A., Mattis, I., Veselovskii, I., Haarig, M., Seifert, P., Engelmann, R., and Wandinger, U.: Extreme levels of Canadian wildfire smoke in the stratosphere over central Europe on 21-22 August 2017, Atmos. Chem. Phys., 18, 11831-11845, https://doi.org/10.5194/acp-18-118312018, 2018.

Baars, H., Kanitz, T., Engelmann, R., Althausen, D., Heese, B., Komppula, M., Preißler, J., Tesche, M., Ansmann, A., Wandinger, U., Lim, J.-H., Ahn, J. Y., Stachlewska, I. S., Amiridis, V., Marinou, E., Seifert, P., Hofer, J., Skupin, A., Schneider, F., Bohlmann, S., Foth, A., Bley, S., Pfüller, A., Giannakaki, E., Lihavainen, H., Viisanen, Y., Hooda, R. K., Pereira, S. N., Bortoli, D., Wagner, F., Mattis, I., Janicka, L., Markowicz, K. M., Achtert, P., Artaxo, P., Pauliquevis, T., Souza, R. A. F., Sharma, V. P., van Zyl, P. G., Beukes, J. P., Sun, J., Rohwer, E. G., Deng, R., Mamouri, R.-E., and Zamorano, F.: An overview of the first decade of Polly ${ }^{\text {NET }}$ : an emerging network of automated Raman-polarization lidars for continuous aerosol profiling, Atmos. Chem. Phys., 16, 5111-5137, https://doi.org/10.5194/acp16-5111-2016, 2016.

Baars, H., Geiß, A., Wandinger, U., Herzog, A., Engelmann, R., Bühl, J., Radenz, M., Seifert, P., Althausen, D., Heese, B., Ansmann, A., Martin, A., Leinweber, R., Lehmann, V., Weissmann, M., Cress, A., Filioglou, M., Komppula, M., and Reitebuch, O.: First results from the German $\mathrm{Cal} / \mathrm{Val}$ activities for Aeolus, in: Proceedings of the 29th International Laser Radar Conference (ILRC), 24-28 June 2019, Hefei, Anhui, China, S1-40-S1-43, 2019a.

Baars, H., Ansmann, A., Ohneiser, K., Haarig, M., Engelmann, R., Althausen, D., Hanssen, I., Gausa, M., Pietruczuk, A., Szkop, A., Stachlewska, I. S., Wang, D., Reichardt, J., Skupin, A., Mattis, I., Trickl, T., Vogelmann, H., Navas-Guzmán, F., Haefele, A., Acheson, K., Ruth, A. A., Tatarov, B., Müller, D., Hu, Q., Podvin, T., Goloub, P., Veselovskii, I., Pietras, C., Haeffelin, M., Fréville, P., Sicard, M., Comerón, A., Fernández García, A. J., Molero Menéndez, F., Córdoba-Jabonero, C., Guerrero-Rascado, J. L., Alados-Arboledas, L., Bortoli, D., Costa, M. J., Dionisi, D., Liberti, G. L., Wang, X., Sannino, A., Papagiannopoulos, N., Boselli, A., Mona, L., D’Amico, G., Romano, S., Perrone, M. R., Belegante, L., Nicolae, D., Grigorov, I., Gialitaki, A., Amiridis, V., Soupiona, O., Papayannis, A., Mamouri, R.-E., Nisantzi, A., Heese, B., Hofer, J., Schechner, Y. Y., Wandinger, U., and Pappalardo, G.: The unprecedented 2017-2018 stratospheric smoke event: decay phase and aerosol properties observed with the EARLINET, Atmos. Chem. Phys., 19, 1518315198, https://doi.org/10.5194/acp-19-15183-2019, 2019b. 
Boers, R., de Laat, A. T., Stein Zweers, D. C., and Dirksen, R. J.: Lifting potential of solar-heated aerosol layers, Geophys. Res. Lett., 37, L24802, https://doi.org/10.1029/2010GL045171, 2010.

Bühl, J., Seifert, P., Wandinger, U., Baars, H., Kanitz, T., Schmidt, J., Myagkov, A., Engelmann, R., Skupin, A., Heese, B., Klepel, A., Althausen, D., and Ansmann, A.: LACROS: the Leipzig Aerosol and Cloud Remote Observations System, Proc. SPIE, 8890, 889002, https://doi.org/10.1117/12.2030911, 2013.

Bühl, J., Seifert, P., Myagkov, A., and Ansmann, A.: Measuring ice- and liquid-water properties in mixed-phase cloud layers at the Leipzig Cloudnet station, Atmos. Chem. Phys., 16, 1060910620, https://doi.org/10.5194/acp-16-10609-2016, 2016.

Burton, S. P., Ferrare, R. A., Hostetler, C. A., Hair, J. W., Rogers, R. R., Obland, M. D., Butler, C. F., Cook, A. L., Harper, D. B., and Froyd, K. D.: Aerosol classification using airborne High Spectral Resolution Lidar measurements - methodology and examples, Atmos. Meas. Tech., 5, 73-98, https://doi.org/10.5194/amt-5-732012, 2012.

Burton, S. P., Hair, J. W., Kahnert, M., Ferrare, R. A., Hostetler, C. A., Cook, A. L., Harper, D. B., Berkoff, T. A., Seaman, S. T., Collins, J. E., Fenn, M. A., and Rogers, R. R.: Observations of the spectral dependence of linear particle depolarization ratio of aerosols using NASA Langley airborne High Spectral Resolution Lidar, Atmos. Chem. Phys., 15, 13453-13473, https://doi.org/10.5194/acp-15-13453-2015, 2015.

CALIPSO: Cloud-Aerosol Lidar and Infrared Pathfinder Satellite Observation Lidar Level 2 Vertical Feature Mask data, ValStage 1 V3-40, available at: https://search.earthdata.nasa.gov/search/ granules? $\mathrm{p}=\mathrm{C} 1356785518$-LARC_ASDC\&tl $=1567329628$ !4! !, last access: 20 April 2020.

Dahlkötter, F., Gysel, M., Sauer, D., Minikin, A., Baumann, R., Seifert, P., Ansmann, A., Fromm, M., Voigt, C., and Weinzierl, B.: The Pagami Creek smoke plume after long-range transport to the upper troposphere over Europe - aerosol properties and black carbon mixing state, Atmos. Chem. Phys., 14, 6111-6137, https://doi.org/10.5194/acp-14-6111-2014, 2014.

Dai, G., Althausen, D., Hofer, J., Engelmann, R., Seifert, P., Bühl, J., Mamouri, R.-E., Wu, S., and Ansmann, A.: Calibration of Raman lidar water vapor profiles by means of AERONET photometer observations and GDAS meteorological data, Atmos. Meas. Tech., 11, 2735-2748, https://doi.org/10.5194/amt11-2735-2018, 2018.

de Laat, A. T. J., Stein Zweers, D. C., Boers, R., and Tuinder, O. N. E.: A solar escalator: Observational evidence of the self-lifting of smoke and aerosols by absorption of solar radiation in the February 2009 Australian Black Saturday plume, J. Geophys. Res., 117, D04204, https://doi.org/10.1029/2011JD017016, 2012.

Ditas, J., Ma, N., Zhang, Y., Assmann, D., Neumaier, M., Riede, H., Karu, E., Williams, J., Scharffe, D., Wang, Q., Saturno, J., Schwarz, J. P., Katich, J. M., McMeeking, G. R., Zahn, A., Hermann, M., Brenninkmeijer, C. A. M., Andreae, M. O., Pöschl, U., Su, H., and Cheng, Y.: Strong impact of wildfires on the abundance and aging of black carbon in the lowermost stratosphere, P. Natl. Acad. Sci. USA, 115, E11595-E11603, https://doi.org/10.1073/pnas.1806868115, 2018.

Engelmann, R., Kanitz, T., Baars, H., Heese, B., Althausen, D., Skupin, A., Wandinger, U., Komppula, M., Stachlewska, I. S., Amiridis, V., Marinou, E., Mattis, I., Linné, H., and Ansmann, A.: The automated multiwavelength Raman polarization and water-vapor lidar Polly ${ }^{X T}$ : the neXT generation, Atmos. Meas. Tech., 9, 1767-1784, https://doi.org/10.5194/amt-9-1767-2016, 2016.

ESA: European Space Agency, ADM-Aeolus Science Report, ESA SP-1311, available at: http://esamultimedia.esa.int/ docs/730SP-1311_ADM-Aeolusa_FINA_low-res.pdf (last access: 20 April 2020), 2008.

FIRMS: Fire Information for Resource Management System providing near real-time active fire data from MODIS (Moderate Resolution Imaging Spectroradiometer) and VIIRS (Visible Infrared Imaging Radiometer Suite), fire information, available at: https://firms.modaps.eosdis.nasa.gov/map/\#z:5;c:144.3, -27.9;t:adv-points;d:2019-12-20..2020-01-20;1:firms_viirs, last access: 20 April 2020.

Flamant, P., Cuesta, J., Denneulin, M. L., Dabas, A., and Huber, D.: ADM-Aeolus retrieval algorithms for aerosol and cloud products, Tellus A, 60, 273-288, https://doi.org/10.1111/j.16000870.2007.00287.x, 2008.

Floutsi, A. A., Baars, H., Radenz, M., Haarig, M., Yin, Z., Seifert, P., Jimenez, C., Wandinger, U., Engelmann, R., Barja, B., Zamorano, F., and Ansmann, A.: Biomass burning aerosols in the southern hemispheric midlatitudes as observed with a multiwavelength polarization Raman lidar, Atmos. Chem. Phys. Discuss., https://doi.org/10.5194/acp-2020-453, in review, 2020.

Foth, A., Kanitz, T., Engelmann, R., Baars, H., Radenz, M., Seifert, P., Barja, B., Fromm, M., Kalesse, H., and Ansmann, A.: Vertical aerosol distribution in the southern hemispheric midlatitudes as observed with lidar in Punta Arenas, Chile $\left(53.2^{\circ} \mathrm{S}\right.$ and $70.9^{\circ} \mathrm{W}$ ), during ALPACA, Atmos. Chem. Phys., 19, 62176233, https://doi.org/10.5194/acp-19-6217-2019, 2019.

Fromm, M. D. and Servranckx, R.: Transport of forest fire smoke above the tropopause by supercell convection, Geophys. Res. Lett., 30, 1542, https://doi.org/10.1029/2002GL016820, 2003.

Fromm, M., Shettle, E. P., Fricke, K. H., Ritter, C., Trickl, T., Giehl, H., Gerding, M., Barnes, J. E., O’Neill, M., Massie, S. T., Blum, U., McDermid, I. S., Leblanc, T., and Deshler, T.: Stratospheric impact of the Chisholm pyrocumulonimbus eruption: 2. Vertical profile perspective, J. Geophys. Res., 113, D08203, https://doi.org/10.1029/2007JD009147, 2008.

Fromm, M., Lindsey, D. T., Servranckx, R., Yue, G., Trickl, T., Sica, R., Doucet, P., and Godin-Beekmann, S. E.: The untold story of pyrocumulonimbus, B. Am. Meteorol. Soc., 91, 1193-1209, https://doi.org/10.1175/2010bams3004.1, 2010.

GDAS: Global Data Assimilation System, meteorological data base, available at: https://www.ready.noaa.gov/gdas1.php, last access: 20 January 2020.

Gialitaki, A., Tsekeri, A., Amiridis, V., Ceolato, R., Paulien, L., Kampouri, A., Gkikas, A., Solomos, S., Marinou, E., Haarig, M., Baars, H., Ansmann, A., Lapyonok, T., Lopatin, A., Dubovik, O., Groß, S., Wirth, M., and Balis, D.: Is the near-spherical shape the "new black" for smoke?, Atmos. Chem. Phys. Discuss., https://doi.org/10.5194/acp-2020-22, in review, 2020.

Giannakaki, E., van Zyl, P. G., Müller, D., Balis, D., and Komppula, M.: Optical and microphysical characterization of aerosol layers over South Africa by means of multi-wavelength depolarization and Raman lidar measurements, Atmos. Chem. Phys., 16, 81098123, https://doi.org/10.5194/acp-16-8109-2016, 2016.

Groß, S., Esselborn, M., Weinzierl, B., Wirth, M., Fix, A., and Petzold, A.: Aerosol classification by airborne high spectral reso- 
lution lidar observations, Atmos. Chem. Phys., 13, 2487-2505, https://doi.org/10.5194/acp-13-2487-2013, 2013.

Haarig, M., Ansmann, A., Baars, H., Jimenez, C., Veselovskii, I., Engelmann, R., and Althausen, D.: Depolarization and lidar ratios at 355, 532, and $1064 \mathrm{~nm}$ and microphysical properties of aged tropospheric and stratospheric Canadian wildfire smoke, Atmos. Chem. Phys., 18, 11847-11861, https://doi.org/10.5194/acp-18-11847-2018, 2018.

Himawari: Data base of the 8th of the Himawari geostationary weather satellites operated by the Japan Meteorological Agency, cloud information, available at: https://himawari8.nict.go.jp/, last access: 20 April 2020.

Himawari-Kachelmann-Wetter: Cloud top temperatures based on Himawari-8 cloud observations, available at: https://kachelmannwetter.com/de/sat/newsouthwales/ top-alarm-10min/20200123-1150z.html, last access: 20 April 2020.

Hofer, J., Althausen, D., Abdullaev, S. F., Makhmudov, A. N., Nazarov, B. I., Schettler, G., Engelmann, R., Baars, H., Fomba, K. W., Müller, K., Heinold, B., Kandler, K., and Ansmann, A.: Long-term profiling of mineral dust and pollution aerosol with multiwavelength polarization Raman lidar at the Central Asian site of Dushanbe, Tajikistan: case studies, Atmos. Chem. Phys., 17, 14559-14577, https://doi.org/10.5194/acp-17-145592017, 2017.

Holben, B. N., Eck, T. F., Slutsker, I., Tanré, D., Buis, J. P., Setzer, A., Vermote, E., Reagan, J. A., Kaufman, Y. J., Nakajima, T., Lavenu, F., Jankowiak, I., and Smirnov, A.: AERONET - a federated instrument network and data archive for aerosol characterization, Remote Sens. Environ., 66, 1-16, 1998.

Hu, Q., Goloub, P., Veselovskii, I., Bravo-Aranda, J.-A., Popovici, I. E., Podvin, T., Haeffelin, M., Lopatin, A., Dubovik, O., Pietras, C., Huang, X., Torres, B., and Chen, C.: Long-rangetransported Canadian smoke plumes in the lower stratosphere over northern France, Atmos. Chem. Phys., 19, 1173-1193, https://doi.org/10.5194/acp-19-1173-2019, 2019.

HYSPLIT: HYbrid Single-Particle Lagrangian Integrated Trajectory model, backward trajectory calculation tool, available at: http://ready.arl.noaa.gov/HYSPLIT_traj.php, last access: 20 January 2020.

Kahnert, M.: Optical properties of black carbon aerosols encapsulated in a shell of sulfate: comparison of the closed cell modell with a coated aggregate model, Opt. Express, 25, 24579-24593, https://doi.org/10.1364/OE.25.024579, 2017.

Kanitz, T., Seifert, P., Ansmann, A., Engelmann, R., Althausen, D., Casiccia, C., and Rohwer, E. G.: Contrasting the impact of aerosols at northern and southern midlatitudes on heterogeneous ice formation, Geophys. Res. Lett., 38, L17802, https://doi.org/10.1029/2011GL048532, 2011.

Kar, J., Lee, K.-P., Vaughan, M. A., Tackett, J. L., Trepte, C. R., Winker, D. M., Lucker, P. L., and Getzewich, B. J.: CALIPSO level 3 stratospheric aerosol profile product: version 1.00 algorithm description and initial assessment, Atmos. Meas. Tech., 12, 6173-6191, https://doi.org/10.5194/amt-12-6173-2019, 2019.

Khaykin, S. M., Godin-Beekmann, S., Hauchecorne, A., Pelon, J., Ravetta, F., and Keckut, P.: Stratospheric smoke with unprecedentedly high backscatter observed by lidars above southern France, Geophys. Res. Lett., 45, 1639-1646, https://doi.org/10.1002/2017GL076763, 2018.
Kloss, C., Berthet, G., Sellitto, P., Ploeger, F., Bucci, S., Khaykin, S., Jégou, F., Taha, G., Thomason, L. W., Barret, B., Le Flochmoen, E., von Hobe, M., Bossolasco, A., Bègue, N., and Legras, B.: Transport of the 2017 Canadian wildfire plume to the tropics via the Asian monsoon circulation, Atmos. Chem. Phys., 19, 13547-13567, https://doi.org/10.5194/acp-19-135472019, 2019.

LACROS: LACROS data base, available at: http://lacros.rsd.tropos. de/, last access: 20 April 2020.

Liu, L. and Mishchenko, M. I.: Scattering and radiative properties of morphologically complex carbonaceous aerosols: A systematic modeling study, Remote Sens., 10, 1634, https://https://doi.org/10.3390/rs10101634, 2018.

Liu, L. and Mishchenko, M. I.: Spectrally dependent linear depolarization and lidar ratios for nonspherical smoke aerosols, J. Quant. Spectrosc. Ra., 248, 106953, https://doi.org/10.1016/j.jqsrt.2020.106953, 2020.

Luo, J., Zhang, Q., Luo, J., Liu, J., Huo, Y., and Zhang, Y.: Optical modeling of black carbon with different coating materials: The effect of coating configurations. J. Geophys. Res.-Atmos., 124, 13230-13253, https://doi.org/10.1029/2019JD031701, 2019.

Lux, O., Lemmerz, C., Weiler, F., Marksteiner, U., Witschas, B., Rahm, S., Geiß, A., and Reitebuch, O.: Intercomparison of wind observations from the European Space Agency's Aeolus satellite mission and the ALADIN Airborne Demonstrator, Atmos. Meas. Tech., 13, 2075-2097, https://doi.org/10.5194/amt13-2075-2020, 2020.

McConnell, J. C. and Jin, J. J.: Stratospheric ozone chemistry, Atmos. Ocean, 46, 69-92, https://doi.org/10.3137/ao.460104, 2010.

MODIS: Moderate Resolution Imaging Spectroradiometer cloud top height information, available at: https: //go.nasa.gov/2YdOaYH, last access: 20 April 2020a.

MODIS: MODIS aerosol optical depth information, Combined Dark Target, Deep Blue AOT at $550 \mathrm{~nm}$, available at: https://worldview.earthdata.nasa.gov/?v=91.22420985977917, last access: 20 April 2020b.

Müller, D., Mattis, I., Wandinger, U., Ansmann, A., Althausen, A., and Stohl, A.: Raman lidar observations of aged Siberian and Canadian forest fire smoke in the free troposphere over Germany in 2003: Microphysical particle characterization, J. Geophys. Res., 110, D17201, https://doi.org/10.1029/2004JD005756, 2005.

Müller, D., Ansmann, A., Mattis, I., Tesche, M., Wandinger, U., Althausen, D., and Pisani, G.: Aerosol-type-dependent lidar ratios observed with Raman lidar, J. Geophys. Res., 112, D16202, https://doi.org/10.1029/2006JD008292, 2007.

Nicolae, D., Vasilescu, J., Talianu, C., Binietoglou, I., Nicolae, V., Andrei, S., and Antonescu, B.: A neural network aerosol-typing algorithm based on lidar data, Atmos. Chem. Phys., 18, 1451114537, https://doi.org/10.5194/acp-18-14511-2018, 2018.

Omar, A. H., Winker, D. M., Vaughan, M. A., Hu, Y., Trepte, C. R., Ferrare, R. A., Lee, K. P., Hostetler, C. A., Kittaka, C., Rogers, R. R., and Kuehn, R. E.: The CALIPSO Automated Aerosol Classification and Lidar Ratio Selection Algorithm, J. Atmos. Ocean. Tech., 26, 1994-2014, https://doi.org/10.1175/2009JTECHA1231.1, 2009.

OMI: Ozone Monitoring Instrument data base, time-averaged daily maps of AOT at $500 \mathrm{~nm}$ with 1 degree resolution (OMI 
OMAERUVd v003) from the NASA Earth Observing System (EOS) Aura satellite for January 20-31, 2020, downloaded from Giovanni online data system, maintained by NASA GES DISC. The average AOT was calculated online and downloaded as one GeoTIFF file to ArvGIS environment for further processing and creating maps, AOT data, available at: https://earthdata.nasa.gov/earth-observation-data/ near-real-time/download-nrt-data/omi-nrt, last access: 20 April 2020.

Papagiannopoulos, N., Mona, L., Amodeo, A., D’ Amico, G., Gumà Claramunt, P., Pappalardo, G., Alados-Arboledas, L., GuerreroRascado, J. L., Amiridis, V., Kokkalis, P., Apituley, A., Baars, H., Schwarz, A., Wandinger, U., Binietoglou, I., Nicolae, D., Bortoli, D., Comerón, A., Rodríguez-Gómez, A., Sicard, M., Papayannis, A., and Wiegner, M.: An automatic observation-based aerosol typing method for EARLINET, Atmos. Chem. Phys., 18, 1587915901, https://doi.org/10.5194/acp-18-15879-2018, 2018.

Peterson, D. A., Campbell, J. R., Hyer, E. J., Fromm, M. D., Kablick III, G. P., Cossuth, J. H., and DeLand, M. T.: Wildfire-driven thunderstorms cause a volcano-like stratospheric injection of smoke, npj Clim. Atmos. Sci., 1, 30, https://doi.org/10.1038/s41612-018-0039-3, 2018.

PollyNet: PollyNET lidar data base, available at: http://polly.rsd. tropos.de/, last access: 8 April 2020.

Renard, J.-B., Brogniez, C., Berthet, G., Bourgeois, Q., Gaubicher, B., Chartier, M., Balois, J.-Y., Verwaerde, C., Auriol, F., Francois, P., Daugeron, D., and Engrand, C.: Vertical distribution of the different types of aerosols in the stratosphere: Detection of solid particles and analysis of their spatial variability, J. Geophys. Res., 113, D21303, https://doi.org/10.1029/2008JD010150, 2008.

Rolph, G., Stein, A., and Stunder, B.: Real-time Environmental Applications and Display sYstem: READY, Environ. Modell. Softw., 95, 210-228, https://doi.org/10.1016/j.envsoft.2017.06.025, 2017.

Sakai, T., Uchino, O., Nagai, T., Liley, B., Morino, I., and Fujimoto, T.: Long-term variation of stratospheric aerosols observed with lidars over Tsukuba, Japan, from 1982 and Lauder, New Zealand, from 1992 to 2015, J. Geophys. Res.-Atmos., 121, 10283-10293, https://doi.org/10.1002/2016JD025132, 2016.

Stein, A. F., Draxler, R. R, Rolph, G. D., Stunder, B. J. B., Cohen, M. D., and Ngan, F.: NOAA's HYSPLIT atmospheric transport and dispersion modeling system, B. Am. Meteorol. Soc., 96, 2059-2077, https://doi.org/10.1175/BAMS-D-14-00110.1, 2015

Stoffelen, A., Pailleux, J., Källén, E., Vaughan, J. M., Isaksen, L., Flamant, P., Wergen, W., Andersson, E., Schyberg, H., Culoma, A., Meynart, R., Endemann, M., and Ingmann, P.: The atmospheric dynamics mission for global wind field measurement, B. Am. Meteorol. Soc., 86, 73-88, https://doi.org/10.1175/BAMS86-1-73, 2005.
Tesche, M., Müller, D., Groß, S., Ansmann, A., Althausen, D., Freudenthaler, V., Weinzierl, B., Veira, A., and Petzold, A.: Optical and microphysical properties of smoke over Cape Verde inferred from multiwavelength lidar measurements, Tellus B, 63, 677-694, https://doi.org/10.1111/j.1600-0889.2011.00549.x, 2011.

Torres, O., Bhartia, P. K., Taha, G., Jethva, H., Das, S., Colarco, P., Krotkov, N., Omar, A., and Ahn, C.: Stratospheric Injection of Massive Smoke Plume from Canadian Boreal Fires in 2017 as seen by DSCOVR-EPIC, CALIOP and OMPS-LP Observations, J. Geophys. Res.-Atmos., 125, e2020JD032579, https://doi.org/10.1029/2020JD032579, 2020a.

Torres, O., Jethva, H., Ahn, C., Jaross, G., and Loyola, D. G.: TROPOMI Aerosol Products: Evaluation and Observations of Synoptic Scale Carbonaceous Aerosol Plumes during 20182020, Atmos. Meas. Tech. Discuss., https://doi.org/10.5194/amt2020-124, in review, 2020b.

Ullrich, R., Hoose, C., Möhler, O., Niemand, M., Wagner, R., Höhler, K., Hiranuma, N., Saathoff, H., and Leisner, T.: A new ice nucleation active site parameterization for desert dust and soot, J. Atmos. Sci., 74, 699-717, 2017.

Wandinger, U., Amiridis, V., Freudenthaler, V., Komppula, M., Kokkalis, P., Engelmann, R., Marinou, E., and Tsekeri, A.: Validation of ADM-Aeolus L2 aerosol and cloud products employing advanced ground-based lidar measurements (VADAM), in: ADM-Aeolus Science and CAL/VAL Workshop, ESA-ESRIN, Frascati, Italy, ESA-ESRIN, 10-13 February 2015.

Winker, D. M., Vaughan, M. A., Omar, A., Hu, Y., Powell, K. A., Liu, Z., Hunt, W. H., and Young, S. A.: Overview of the CALIPSO mission and CALIOP data processing algorithms, J. Atmos. Ocean. Tech., 26, 2310-2323, https://doi.org/10.1175/2009JTECHA1281.1, 2009.

Witschas, B., Lemmerz, C., Geiß, A., Lux, O., Marksteiner, U., Rahm, S., Reitebuch, O., and Weiler, F.: First validation of Aeolus wind observations by airborne Doppler wind lidar measurements, Atmos. Meas. Tech., 13, 2381-2396, https://doi.org/10.5194/amt-13-2381-2020, 2020.

Yu, P., Toon, O. B., Bardeen, C. G., Zhu, Y., Rosenlof, K. H., Portmann, R. W., Thornberry, T. D., Gao, R.-S., Davis, S. M., Wolf, E. T., de Gouw, J., Peterson, D. A., Fromm, M. D., and Robock, A.: Black carbon lofts wildfire smoke high into the stratosphere to form a persistent plume, Science, 365, 587-590, https://doi.org/10.1126/science.aax1748, 2019. 